\title{
Transcriptional analysis of the bovine herpesvirus 1 Cooper isolate
}

\section{Temporal analysis and characterization of immediate-early, early, and late RNA}

\author{
B. S. Seal ${ }^{1}$, J. M. Irving ${ }^{2}$, and Cecelia A. Whetstone ${ }^{1}$ \\ ${ }^{1}$ Virology Cattle Research Unit, National Animal Disease Center, USDA, \\ Agricultural Research Service, Ames, Iowa, U.S.A. \\ ${ }^{2}$ Institute of Gerontology, University of Michigan, Ann Arbor, Michigan, U.S.A.
}

Accepted April 8, 1991

Summary. Blot hybridization analysis of infected bovine herpesvirus 1 (BHV1) cellular RNA isolated at various times post infection and after treatment with specific metabolic inhibitors was used to characterize transcription of the BHV-1 Cooper isolate. Synthesis of BHV-1 RNA was detected as early as $3 \mathrm{~h}$ post infection and reached a maximum at six to eight hours post infection. The most transcriptionally active area of the genome was between map units 0.110 to 0.195 , within the HindIII I fragment. From the entire genome a total of 59 transcripts ranging in size from approximately 0.6 to 10 kilobases were characterized as belonging to one of three distinct classes. Using the protein synthesis inhibitor cycloheximide, three immediate-early transcripts were identified as originating from the internal inverted repeat region between map units 0.734 and 0.842 , corresponding to the HindIII D fragment. Using phosphonoacetic acid to prevent virus DNA synthesis by inhibition of the BHV-1 DNA polymerase, 28 early transcripts were recognized. The remaining 28 transcripts, classified as late RNA, were detected without the use of metabolic inhibitors at 6 to $8 \mathrm{~h}$ post infection. Transcription of early and late RNA was not restricted to any specific area of the genome. Eighty percent of the transcripts from both the HindIII A fragment, between map units 0.381 to 0.537 within the unique long segment, and the HindIII $\mathrm{K}$ fragment, between map units 0.840 to 0.907 of the unique short segment, were designated as belonging to the early class.

\section{Introduction}

Bovine herpesvirus 1 (BHV-1), family Herpesviridae, genus Simplexvirus, is associated with a variety of clinical syndromes $[27,42,59]$. These are primarily respiratory, but also include genital infections, abortion, and encephalitis $[8$, 
$9,19,34,36,52]$. Infectious bovine rhinotracheitis (IBR) was first described in the U.S. as a respiratory tract disease of cattle in 1955 and the virus was isolated shortly thereafter $[27,35]$. The genital form of the disease known as infectious pustular vulvovaginitis (IPV) was described in 1950 in the U.S., but has been known in Europe since the middle of the 19th century [19, 21, 23].

BHV-1 was first shown to be a DNA virus by replication inhibition in cell culture with deoxynucleotide analogues [50]. The viral DNA has a density of $1.73 \mathrm{~g} / \mathrm{cm}^{3}$, a base composition of $76.7 \% \mathrm{GC}$, and a melting temperature of $82.7^{\circ} \mathrm{C}$ [15]. During infection of cells in culture, virus DNA synthesis begins 4 to $6 \mathrm{~h}$ post infection [46] and extracellular virus appears in the supernatant at 6 to $8 \mathrm{~h}$ post infection $[45,49]$. The genome of BHV-1 is approximately 135 kilobases $(\mathrm{kb})$ with a unique long segment $\left(\mathrm{U}_{\mathrm{L}}\right)$ of $100 \mathrm{~kb}$, an internal repeat $\left(\mathrm{I}_{\mathrm{R}}\right)$ of $11 \mathrm{~kb}$, a unique short segment $\left(\mathrm{U}_{\mathrm{S}}\right)$ of $13 \mathrm{~kb}$ and a terminal repeat $\left(\mathrm{T}_{\mathrm{R}}\right)$ of approximately $11 \mathrm{~kb}$. The $\mathrm{U}_{\mathrm{S}}$ segment may be oriented in two alternative directions, while the $U_{L}$ segment is oriented in only one direction [32]. The genomic termini have been cloned and contain short repeats that may vary in size. These repetitive sequence elements may be functionally important for cleavage and isomerization of virus DNA $[17,18]$.

Polypeptides produced by BHV-1 during infections in cell culture appear in a temporally ordered sequence $[4,31,37]$. The alpha or immediate-early genes are transcribed in the absence of virus protein synthesis, while beta or early gene expression occurs at the start of virus protein synthesis and prior to virus DNA synthesis. The gamma or late genes require the onset of virus DNA synthesis. Approximately 33 virion polypeptides have been identified ranging in molecular weight from $13 \mathrm{k}$ to $275 \mathrm{k} ; 11$ of these proteins can be labeled with $\left[{ }^{3} \mathrm{H}\right]$-glucosamine and were identified as glycoproteins [37].

Several BHV-1 genes have been cloned and mapped to the genome. Like herpes simplex virus (HSV), BHV-1 induces its own thymidine kinase (TK) during productive infection $[22,54]$. The TK gene was subsequently cloned and localized by marker rescue to a $1.1 \mathrm{~kb} B g I I \mathrm{I} / S a I \mathrm{I}$ fragment which maps at 0.47 to 0.48 on the BHV-1 HindIII A fragment [3]. The TK gene of a wildtype BHV-1 isolate and two TK ${ }^{-}$mutants have been sequenced. Five conserved regions of the BHV-1 TK gene are homologous with HSV-1 and -2 and varicella zoster virus TK genes [39]. Using a HSV-1 DNA polymerase gene as a probe, the BHV-1 DNA polymerase gene was localized within a $H p a \mathrm{I} / \mathrm{BamHI}$ subfragment of the HindIII $\mathrm{G}$ fragment [41]. A putative DNA binding protein gene was mapped next to the DNA polymerase gene [2]. Glycoprotein $\mathrm{gI}$ ( $\mathrm{gB}$ homologue of herpes simplex) gene mapped to a $3.8 \mathrm{~kb}$ fragment from 0.405 to 0.432 on the HindIII A fragment of the BHV-1 genome [24, 38, 57]. The glycoprotein gIII ( $\mathrm{gC}$ homologue of herpes simplex) gene has also been cloned, sequenced, and mapped between map units (m.u.) 0.122 to 0.135 of the HindIII I fragment $[12,13]$. Latency associated transcripts of BHV-1 were localized to 0.734 to 0.748 m.u. of the HindIII D fragment [20,44]. Transcriptional analysis of BHV-1, Jura and K22 isolates, has recently been published. Fifty-four tran- 
scripts ranging in size from 0.4 to greater than $8 \mathrm{~kb}$ were identified by RNA blot hybridization analysis. Four transcripts were classified as immediate-early, 21 as early, 12 were considered late, and 17 transcripts could not be classified as early or late using the metabolic inhibitor cytosine arabinoside [58].

We have found a number of discrepancies in the sizes of the transcripts reported previously [58]. Consequently, we have completed a more extensive analysis using cloned fragments representing the $\mathrm{BHV}-1$ Cooper isolate genome to monitor transcription of BHV-1 infected cells temporally and using metabolic inhibitors. The Cooper isolate is the vaccine virus used for BHV-1 in the United States and has been associated with vaccine-induced epizootics [55, 56]. Transcription data presented in this report provides comparative data for possible differential gene expression between the Cooper respiratory and K22 genital type isolates.

\section{Materials and methods}

\section{Cell culture, virus inoculation, virus DNA synthesis, and use of metabolic inhibitors}

Bovine turbinate (BT) or fetal bovine lung (FBL) cells were cultured in Dulbecco's minimum essential medium supplemented with $10 \%$ fetal bovine serum in $150 \mathrm{~cm}^{2}$ flasks as described elsewhere [47]. The Cooper isolate of BHV-1 [32] used throughout these studies was inoculated at a multiplicity of infection of 10 . To monitor BHV-1 DNA synthesis, infected FBL or BT cells in $25 \mathrm{~cm}^{2}$ flasks were harvested at various times post infection (p.i.) and digested with proteinase $\mathrm{K}(1 \mathrm{mg} / \mathrm{ml})$ in the presence of sarkosyl $(1 \%)$ and EDTA $(0.1 \mathrm{M}$, $\mathrm{pH}$ 8.0). Following phenol-chloroform extraction, $2 \mu \mathrm{g}$ of infected cell DNA was slotblotted to nylon membranes (Hybond-N, Amersham, Arlington Heights, IL) and baked at $80^{\circ} \mathrm{C}$ for $2 \mathrm{~h}[5,30]$. Virus-infected cell DNA was also isolated at $5 \mathrm{~h}$ p.i. in the presence of 50,100 , and $150 \mu \mathrm{g} / \mathrm{ml}$ cycloheximide $(\mathrm{CH})$ and at $6 \mathrm{~h}$ p.i. in the presence of 200,300 or $400 \mu \mathrm{g} / \mathrm{ml}$ phosphonoacetic acid (PAA). Prehybridization, hybridization with nick-translated ${ }^{32}$ P-labeled BHV-1 DNA and autoradiography were as described in detail previously $[5,30,48]$.

\section{Isolation of $R N A$ and infection protocol}

To determine temporal appearance of BHV-1 transcripts total cell RNA was isolated from infected cells at various times p.i. as indicated in the figure legends. Virus-infected cell RNA was isolated at $5 \mathrm{~h}$ p.i. in the presence of 50,100 , and $150 \mu \mathrm{g} / \mathrm{ml} \mathrm{CH}$ and at $6 \mathrm{~h}$ p.i. in the presence of 200,300 , or $400 \mu \mathrm{g} / \mathrm{ml}$ PAA to determine optimum concentrations of metabolic inhibitors prior to extensive hybridization analysis. Subsequently, for metabolic inhibition studies, cells were treated with $\mathrm{CH}$ at $100 \mu \mathrm{g} / \mathrm{ml}$ to detect immediate-early transcripts, or with PAA at $400 \mu \mathrm{g} / \mathrm{ml}$, to detect early transcripts. Drug treatment was from two hours prior to and throughout infection. Late transcripts were classified as those synthesized in the absence of metabolic inhibitors minus the IE and $\mathrm{E}$ transcripts. At the designated times p.i., cells were rinsed 3 times with ice-cold phosphate-buffered saline (PBS is $0.01 \mathrm{M}$ $\mathrm{Na}_{2} \mathrm{HPO}_{4}$ and $0.9 \% \mathrm{NaCl}, \mathrm{pH} 7.5$ ), followed by lysis with guanidinium isothiocyanate ( 4 $\mathrm{M}$ guanidinium isothiocyanate, $0.1 \mathrm{M} \beta$-mercaptoethanol, $10 \mathrm{mM}$ EDTA, $50 \mathrm{mM}$ Tris- $\mathrm{HCl}$, pH 8.2) pipetted directly onto the cell monolayer [6]. A $2.6 \mathrm{ml}$ aliquot of homogenized cells was layered over a $1.2 \mathrm{ml}$ cushion of $5.7 \mathrm{M} \mathrm{CsCl}(10 \mathrm{mM}$ EDTA, $\mathrm{pH} 8.0)$ and centrifuged at $160,000 \times \mathrm{g}$ for $15 \mathrm{~h}$ in a Beckman SW 60 rotor [14]. The RNA pellet was resuspended in $10 \mathrm{mM}$ Tris- $\mathrm{HCl}, 10 \mathrm{mM}$ EDTA at $\mathrm{pH} 8.2$, extracted three times with chloroform- 
butanol (4:1) and stored at $-70^{\circ} \mathrm{C}$ in 2.2 volumes of ethanol with $2 \mathrm{M}$ ammonium acetate. Aliquots, $50 \mu \mathrm{l}$, were pelleted by centrifugation in a cooled $\left(4^{\circ} \mathrm{C}\right)$ microcentrifuge and RNA concentrations were determined spectrophotometrically.

\section{Northern blot hybridization analysis}

Hybridization probes were cloned HindIII fragments of the BHV-1 Cooper genome [32] cut from low-melting agarose gels [51]. Two additional cloned fragments, designated HS and $\mathrm{HK}$, were derived from the left terminus of the HindIII D fragment and hybridize to latency-associated transcripts of BHV-1 [44]. The HS probe corresponds to a HindIII/SalI subclone from the HindIII D fragment representing 0.734 to $0.748 \mathrm{~m} . \mathrm{u}$. and the HK probe is a HindIII/KpnI subclone from 0.734 to 0.778 m.u. of the HindIII D fragment. The EcoRI $\mathrm{E}$ and $\mathrm{F}$ fragments, constituting the termini of the BHV-1 genome [32], were cut from low-melting agarose [51] following restriction endonuclease digestion of intact $\mathrm{BHV}-1$ genomic DNA and agarose gel electrophoresis. Extracted fragments were radioactively labeled with $\left[{ }^{32} \mathrm{P}\right] \mathrm{dCTP}$ and $\left[{ }^{32} \mathrm{P}\right] \mathrm{dATP}$ (specific activity $3,000 \mathrm{Ci} / \mathrm{mmole}$, ICN Radiochemicals, Irvine, CA) using the random-primer method $[10,11]$. Random-primer (Bethesda Research Laboratories, Gaithersburg, MD) labeled probes of $2 \times 10^{9} \mathrm{cpm} / \mu \mathrm{g}$ were routinely obtained and $1 \times 10^{6} \mathrm{cpm}$ per lane of electrophoresed RNA was used during hybridization.

Equal amounts of infected cell RNA $(6 \mu \mathrm{g})$ were fractionated by glyoxal gel electrophoresis in $1.0 \%$ agarose as described previously $[30,33]$. Integrity and RNA concentrations per lane were verified by visualization of ethidium-bromide stained RNA during UV transillumination. Following gel electrophoresis, RNA was transferred to prewetted nylon membranes by capillary action using $20 \times \mathrm{SSC}(1 \times \mathrm{SSC}$ is $0.14 \mathrm{M} \mathrm{NaCl}, 0.015 \mathrm{M}$ sodium citrate, $\mathrm{pH} 8.2$ ) and then fixed to the membrane by baking for $2 \mathrm{~h}$ at $80^{\circ} \mathrm{C}$ under vacuum. Filters with immobilized RNA were prehybridized and hybridized in buffer containing 0.5 $\mathrm{M}$ sodium phosphate, $\mathrm{pH} 7.2,7 \%$ sodium dodecyl sulfate (SDS), $1 \%$ bovine serum albumin (BSA), and $1 \mathrm{mM}$ EDTA (pH 8.0) at $68^{\circ} \mathrm{C}[7,29]$. After hybridization overnight, the filters with bound probe were washed twice in $40 \mathrm{mM}$ phosphate buffer ( $\mathrm{pH} 7.2$ ), $5 \%$ SDS, $0.5 \%$ BSA, $1 \mathrm{mM}$ EDTA ( $\mathrm{pH} \mathrm{8.0)}$ ) for $1 \mathrm{~h}$ at the hybridization temperature and twice more in buffer with $40 \mathrm{mM}$ phosphate $(\mathrm{pH} \mathrm{7.2),1 \%} \mathrm{SDS} \mathrm{and} 1 \mathrm{mM}$ EDTA (pH 8.0) for $1 \mathrm{~h}$ as previously described [29]. Nylon filters with radioactive probes hybridized to immobilized RNA were exposed to Kodak XAR-5 film. Sizes of BHV-1 transcripts were determined by extrapolation between the relative mobilities of known size markers [25] (Bethesda Research Laboratories, Gaithersburg, MD) as designated in the figure legends. Using these conditions no cross-hybridization has been detected with bovine cellular RNA (Fig. 4b, G).

For quantitation of hybridized cloned probe to blotted infected cell RNA, an Ambis radioanalytic imaging system (AMBIS Systems, Inc., San Diego, CA) was used to compare differences in BHV-1 RNA production at different concentrations of $\mathrm{CH}$ and PAA. This was accomplished by placing the blotted infected cell RNA with hybridized radioactive probe in the Ambis gas ionization 2-D detector for $16 \mathrm{~h}$. Following the detection period, a print-out of the amount of radioactivity per lane of RNA was obtained and compared for differences among treatments.

\section{Results}

Inhibition of virus DNA replication and determination of metabolic inhibitor concentrations

To determine optimum concentrations of metabolic inhibitors, the effect of $\mathrm{CH}$ and PAA on virus DNA and RNA synthesis was investigated (Fig. 2). Virus 
Genome Structure

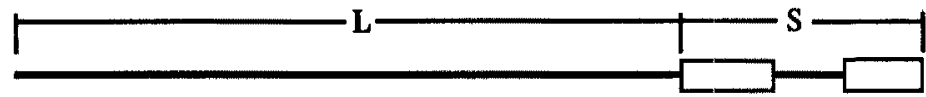

Gene Location

Hind III Fragments

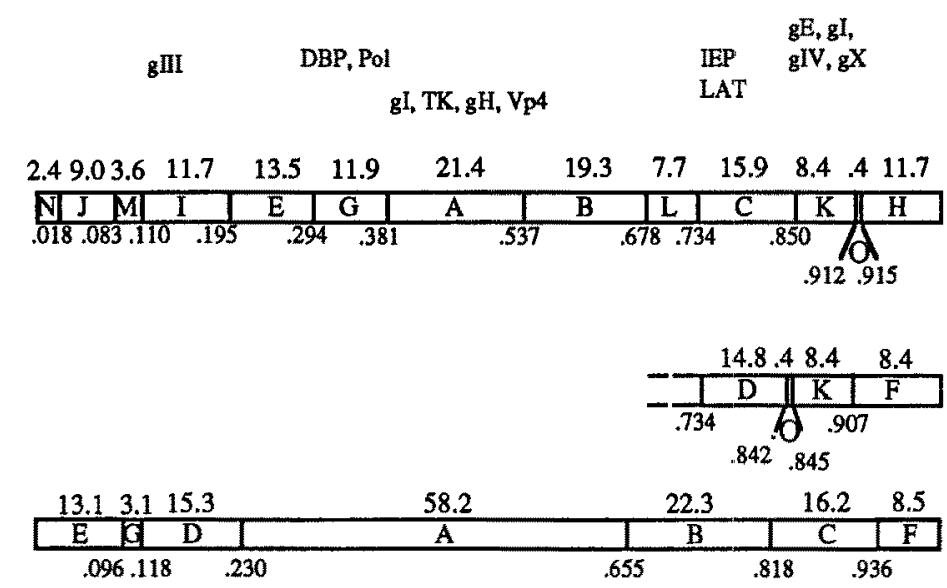

Fig. 1. Genomic structure of the bovine herpesvirus 1 Cooper isolate. Location of the $H$ indIII and $E c o$ RI restriction endonuclease cleavage sites, size of fragments and structure of the virus genome are illustrated. The genome consists of one unique long $\left(L, \mathrm{U}_{\mathrm{L}}\right)$ section and a unique short $(S)$ segment which can occur in reverse orientation with respect to the $\mathrm{U}_{\mathrm{L}}$ segment. Genomic maps were adapted from Mayfield et al. [32] and gene locations are as cited in the text

DNA synthesis was detected at $4.5 \mathrm{~h}$ p.i., reached a maximum at $6.5 \mathrm{~h}$ p.i. and began to decrease at $8 \mathrm{~h}$ p.i. (Fig. $2 \mathrm{~A}$, lane 1). No appreciable DNA synthesis occurred at $5 \mathrm{~h}$ p.i. in the presence of $\mathrm{CH}$ or at $6 \mathrm{~h}$ p.i. in the presence of PAA at any of the concentrations used (Fig. 2 A, lane 2).

Although virus DNA synthesis was inhibited by $\mathrm{CH}$ and PAA at the concentrations used, the amount of RNA present under these conditions was unknown. The HindIII D fragment of BHV-1 DNA was hybridized with RNA from infected cells treated with 50,100 , and $150 \mu \mathrm{g} / \mathrm{ml} \mathrm{CH}$ (Fig. 2 B) at $5 \mathrm{~h} \mathrm{p.i.}$ Radioanalytic imaging analysis revealed that the greatest amount of radioactivity occurred in the lane containing RNA purified from infected cells treated with $100 \mu \mathrm{g} / \mathrm{ml}$ of $\mathrm{CH}$. Both lanes containing RNA from infected cells treated with 50 or $150 \mu \mathrm{g} / \mathrm{ml}$ of $\mathrm{CH}$ routinely contained less hybridized radioactivity (Fig. 2B, lanes 1 and 3) than RNA from infected cells treated with $100 \mu \mathrm{g} / \mathrm{ml}$ $\mathrm{CH}$ (Fig. $2 \mathrm{~B}$, lane 2). Similar experiments were conducted using RNA isolated from BHV-1 infected cells at $6 \mathrm{~h}$ p.i. in the presence of 200,300 , or $400 \mu \mathrm{g} / \mathrm{ml}$ of PAA. Infected cell RNA at $6 \mathrm{~h}$ p.i. at the different concentrations of PAA was analyzed for amount of bound radioactivity following Northern blot hybridization with the HindIII I fragment. No observable difference in the amount of hybridized radioactivity was detected among PAA treatment groups. Using $400 \mu \mathrm{g} / \mathrm{ml} \mathrm{PAA}$ at 6 and $8 \mathrm{~h}$ p.i. (Fig. $2 \mathrm{C}$, lanes 1 and 2) appeared to have no effect on detection of early transcripts, and these could be differentiated from transcripts isolated at $6 \mathrm{~h}$ p.i. without the use of PAA (Fig. $2 \mathrm{C}$, lane 3). Spe- 


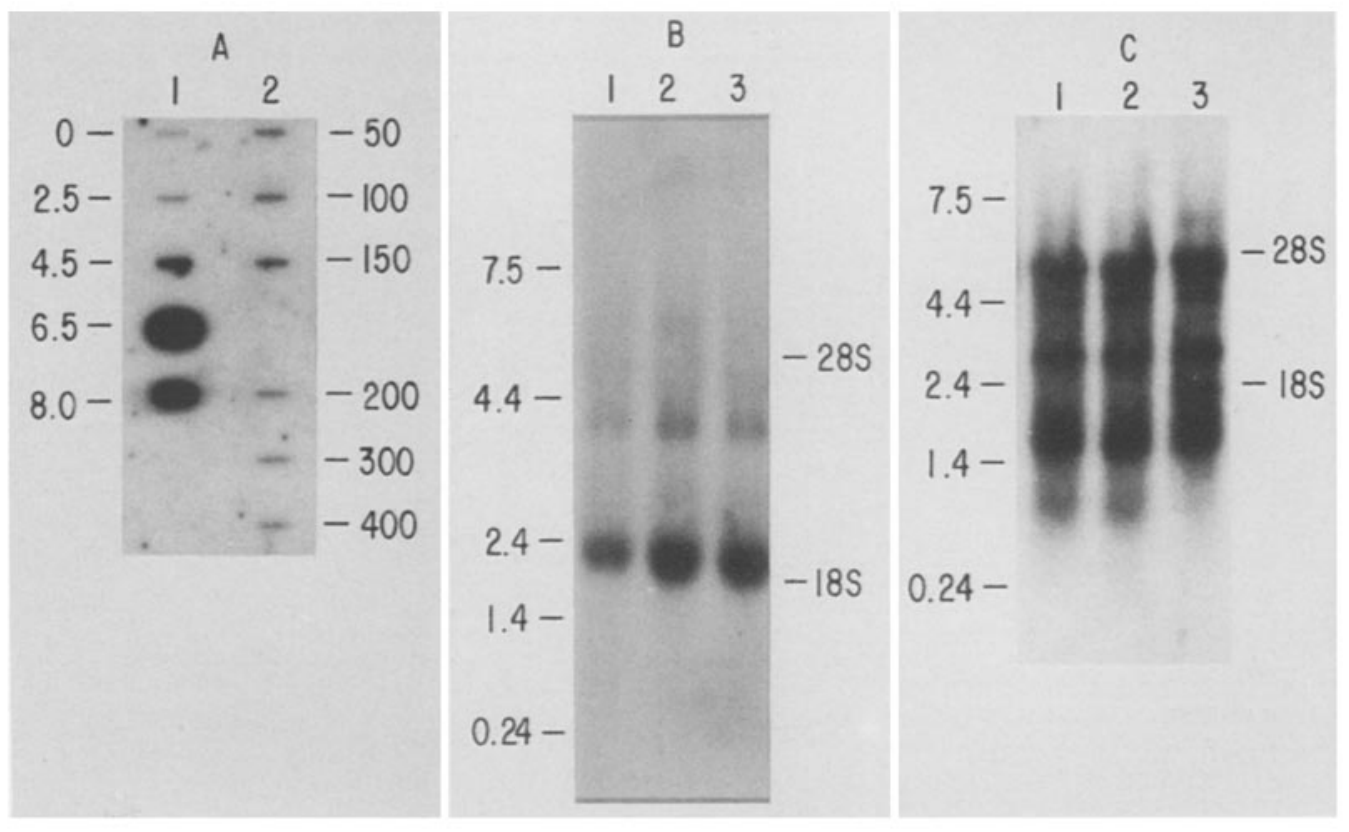

Fig. 2. Effect of metabolic inhibitors on Cooper BHV-1 DNA and RNA synthesis. A Infected cell DNAs at $0,2.5,4.5,6.5$, and $8 \mathrm{~h}$ post infection (p.i.) (l) and in the presence of 50,100 , or $150 \mu \mathrm{g} / \mathrm{ml}$ cycloheximide at $5 \mathrm{~h}$ p.i. or 200,300 , or $400 \mu \mathrm{g} / \mathrm{ml}$ phosphonoacetic acid at $6 \mathrm{~h}$ p.i. (2) were slot-blotted and hybridized with radioactivity labeled BHV-1 genomic DNA. B Blot hybridization of total infected cell RNA with radioactively labeled HindIII $\mathrm{D}$ fragment at $50(1), 100(2)$, or $150(3) \mu \mathrm{g} / \mathrm{ml}$ of cycloheximide. C Blot hybridization of total infected cell RNA in the presence of $400 \mu \mathrm{g} / \mathrm{ml}$ phosphonoacetic acid with radioactively labeled HindIII I fragment at $6(1)$ and $8 \mathrm{~h}$ (2) p.i. 3 Total infected cell RNA at $6 \mathrm{~h}$ p.i. with no metabolic inhibitors and hybridized with radioactivity labeled HindIII fragment I

(3). Molecular size markers in kilobases are noted to the left of $\mathbf{B}$ and $\mathbf{C}$

cifically, a $6.5 \mathrm{~kb}$ late RNA was clearly visible (Fig. 2C, lane 3) at $6 \mathrm{~h}$ p.i. without the use of PAA as compared to RNA purified from cells treated with PAA (Fig. 2C, lanes 1 and 2). A $0.6 \mathrm{~kb}$ early RNA was present in the RNA isolated from cells treated with PAA (Fig. 2C, lanes 1 and 2), but was not detected by 8 h p.i. (Fig. 2 C, lane 3).

\section{Identification of immediate-early transcripts}

To identify immediate-early transcripts, BHV-1 infected cellular RNA was isolated at $5 \mathrm{~h}$ p.i. following treatment of infected cells with $100 \mu \mathrm{g} / \mathrm{ml} \mathrm{CH}$. The RNA was analyzed by Northern blot hybridization with radioactively labeled fragments from the BHV-1 genome. Following temporal analysis of RNA production during active infections in cell culture and analysis of BHV-1 RNA production in the presence of $\mathrm{CH}$, three immediate-early transcripts were identified using the HindIII D fragment (Fig. 5 and Table 1). The HindIII D fragment encompasses the internal inverted repeat section of the BHV-1 genome from 


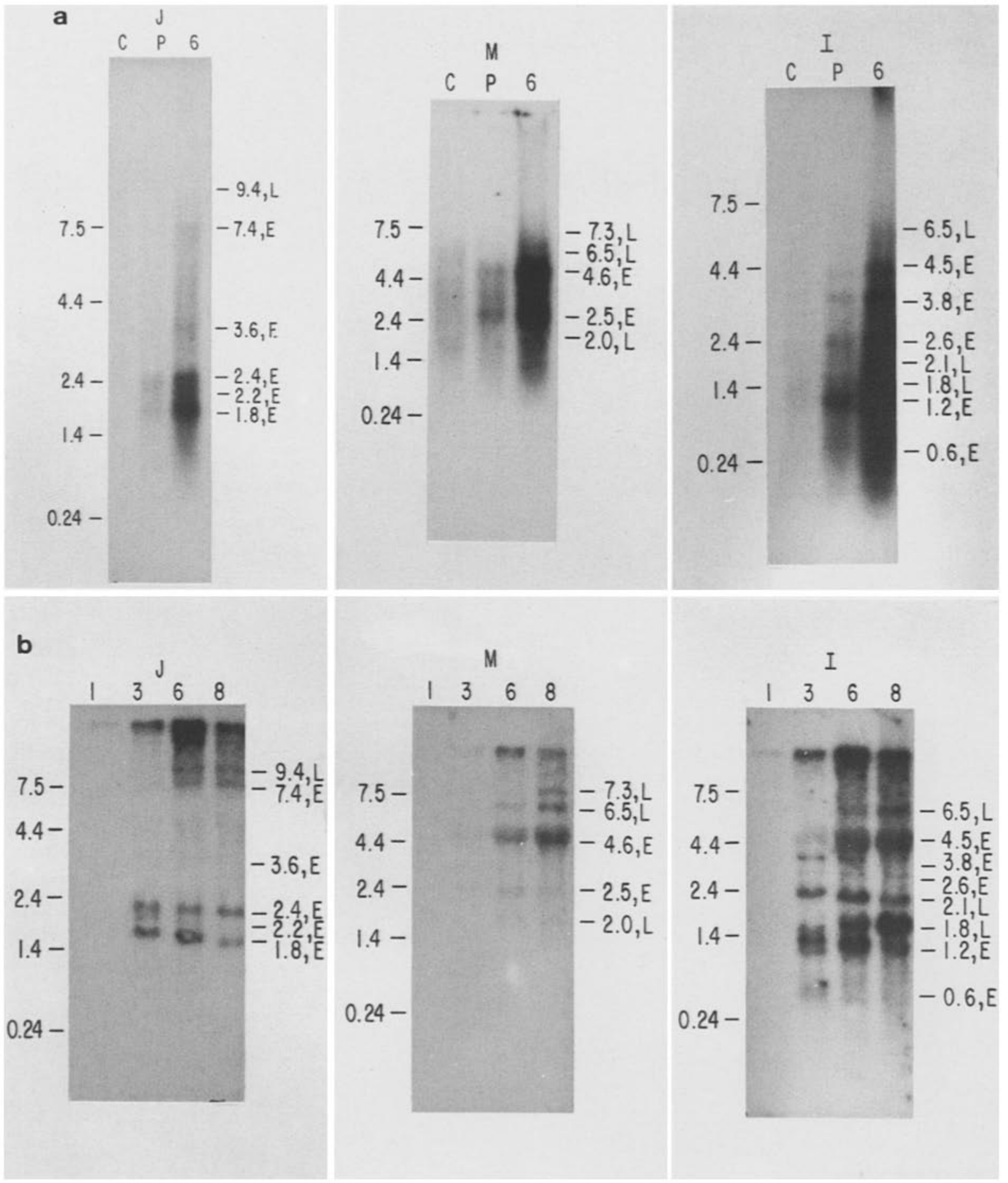

Fig. 3. Blot hybridization analysis of transcripts in BHV-1 Cooper infected cells synthesized from map units 0.018 to 0.195 of the unique long component of the virus genome. Total infected cell RNA was fractionated by glyoxal gel electrophoresis and transferred to nylon filters. Viral RNA was detected by hybridization with ${ }^{32}$ P-labeled BHV-1 DNA from cloned HindIII fragments $\mathrm{J}, \mathrm{M}$, and I followed by autoradiography. a RNA purified from BHV1 infected cells treated with $100 \mu \mathrm{g} / \mathrm{ml}$ cycloheximide $(C), 400 \mu \mathrm{g} / \mathrm{ml}$ phosphonoacetic acid $(P)$ or at $6 \mathrm{~h}$ post infection (p.i.) without drug treatment (6). b RNA purified at various times (h) p.i. as indicated above each lane. Molecular size markers in kilobases are noted to the left of each panel. The size and classification of each viral RNA is in the right-hand margin of each panel and designated as early (E) or late (L) based upon its detection in the presence or absence of phosphonoacetic acid and its time of appearance 


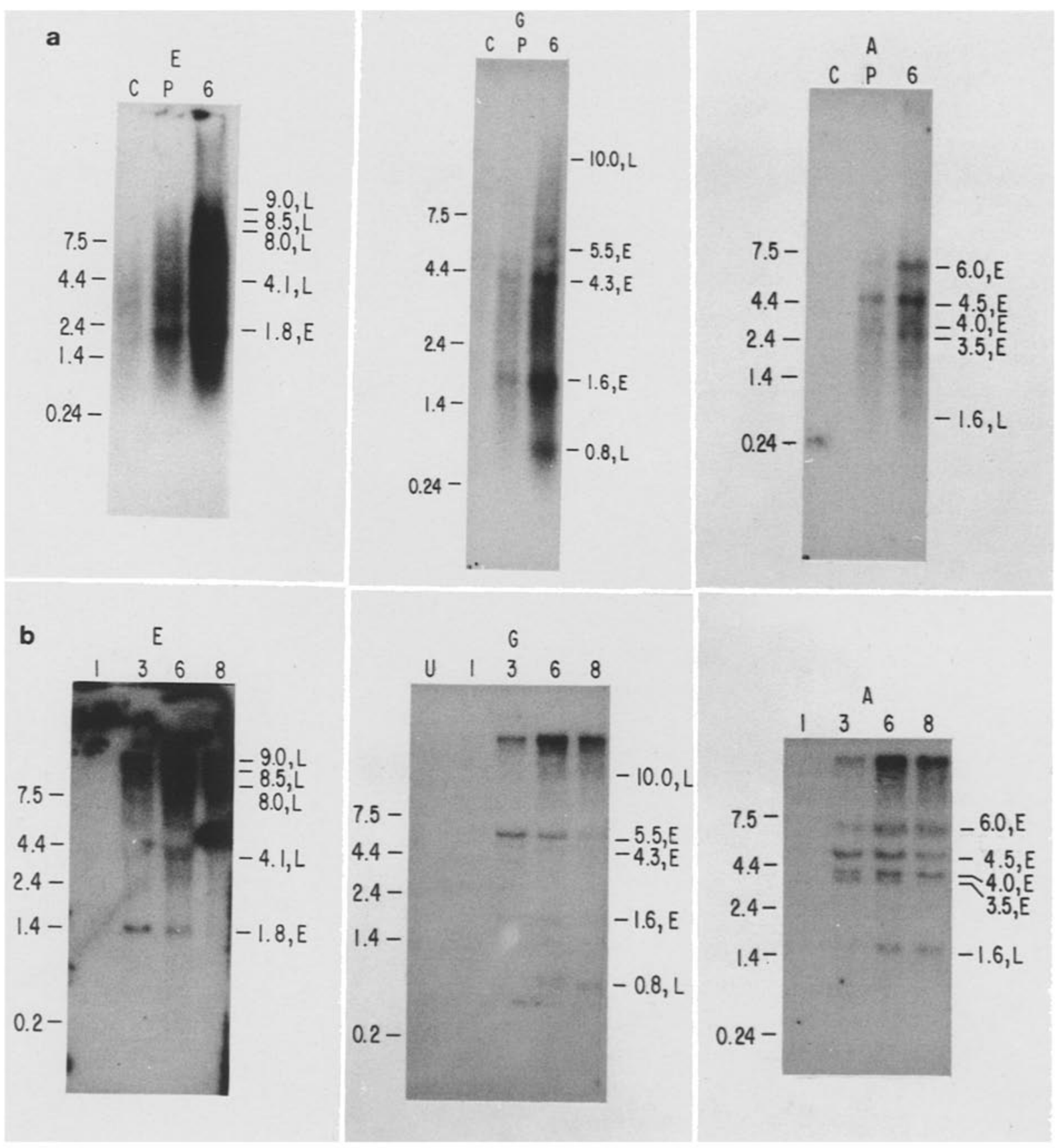

Fig. 4. Blot hybridization analysis of transcripts in BHV-1 Cooper infected cells synthesized from map units 0.195 to 0.537 of the unique long region of the virus genome. Viral RNA was detected by hybridization with ${ }^{32}$ P-labeled BHV-1 DNA from cloned HindIII fragments E, G, and A followed by autoradiography. a RNA purified from BHV-1 infected cells treated with $100 \mu \mathrm{g} / \mathrm{ml}$ cycloheximide $(C), 400 \mu \mathrm{g} / \mathrm{ml}$ phosphonoacetic acid $(P)$ or at $6 \mathrm{~h}$ post infection (p.i.) without drug treatment (6). b RNA purified at various times (h) p.i. as indicated above each lane; $U$ uninfected cell control. Molecular size markers in kilobases are noted to the left of each panel. The size and classification of each viral RNA is in the right-hand margin of each panel and designated as early $(E)$ or late (L) based upon its detection in the presence or absence of phosphonoacetic acid and its time of appearance 


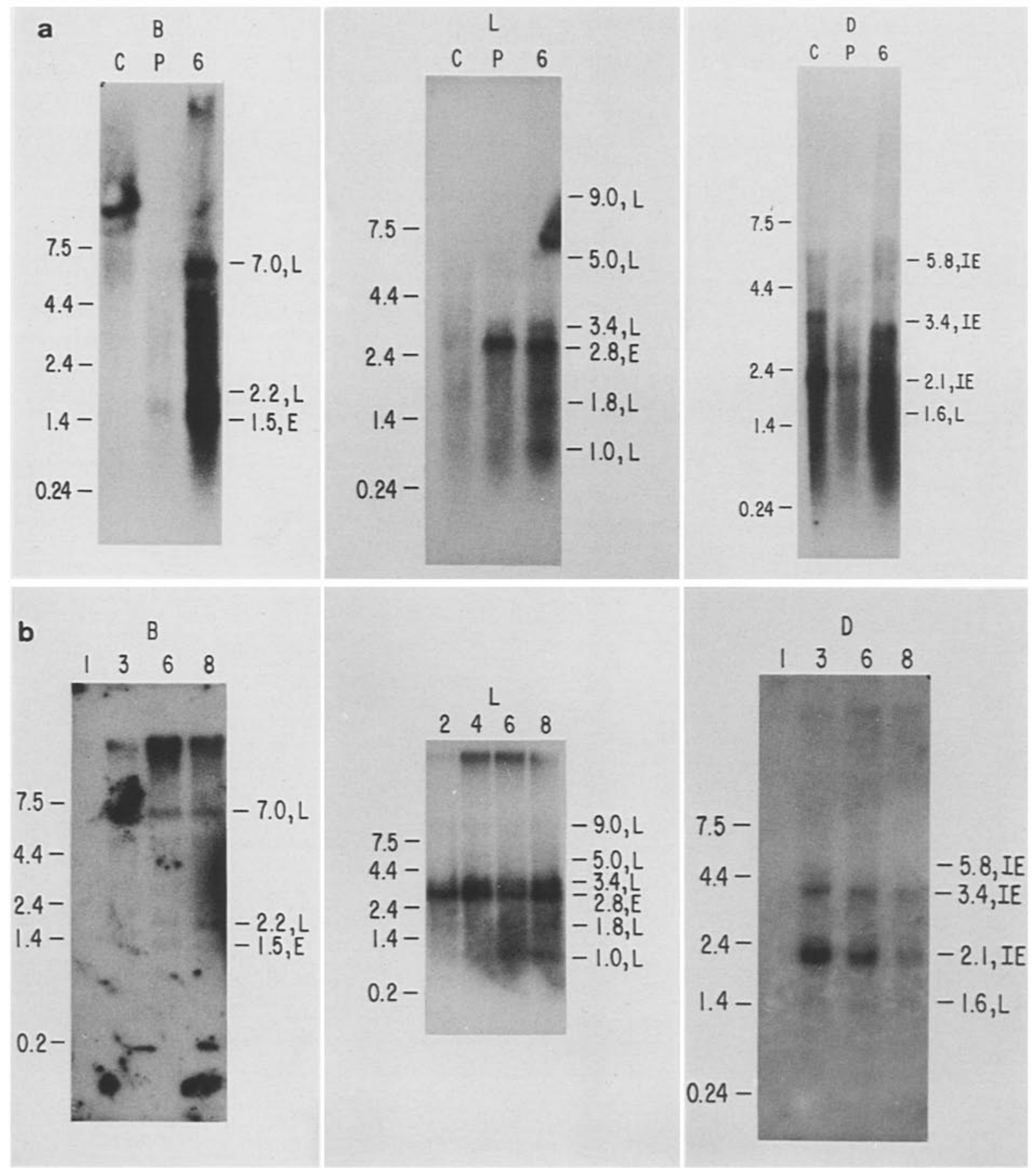

Fig. 5. Blot hybridization analysis of transcripts in BHV-1 Cooper infected cells synthesized from map units 0.537 to 0.842 , covering portions of the unique long, internal inverted repeat and unique short components of the virus genome. Viral RNA was detected by hybridization with ${ }^{32} \mathrm{P}$-labeled BHV-1 DNA from cloned HindIII fragments B, L, and D followed by autoradiography. a RNA purified from BHV-1 infected cells treated with $100 \mu \mathrm{g} / \mathrm{ml}$ cycloheximide $(C), 400 \mu \mathrm{g} / \mathrm{ml}$ phosphonoacetic acid $(P)$ or at $6 \mathrm{~h}$ post infection (p.i.) without drug treatment (6). b RNA purified at various times (h) p.i. as indicated above each lane. Molecular size markers in kilobases are noted to the left of each panel. The size and classification of each viral RNA is in the right-hand margin of each panel and designated as immediate-early (IE), early (E) or late (L) based upon detection in the presence or absence of cycloheximide or phosphonoacetic acid and its time of appearance 


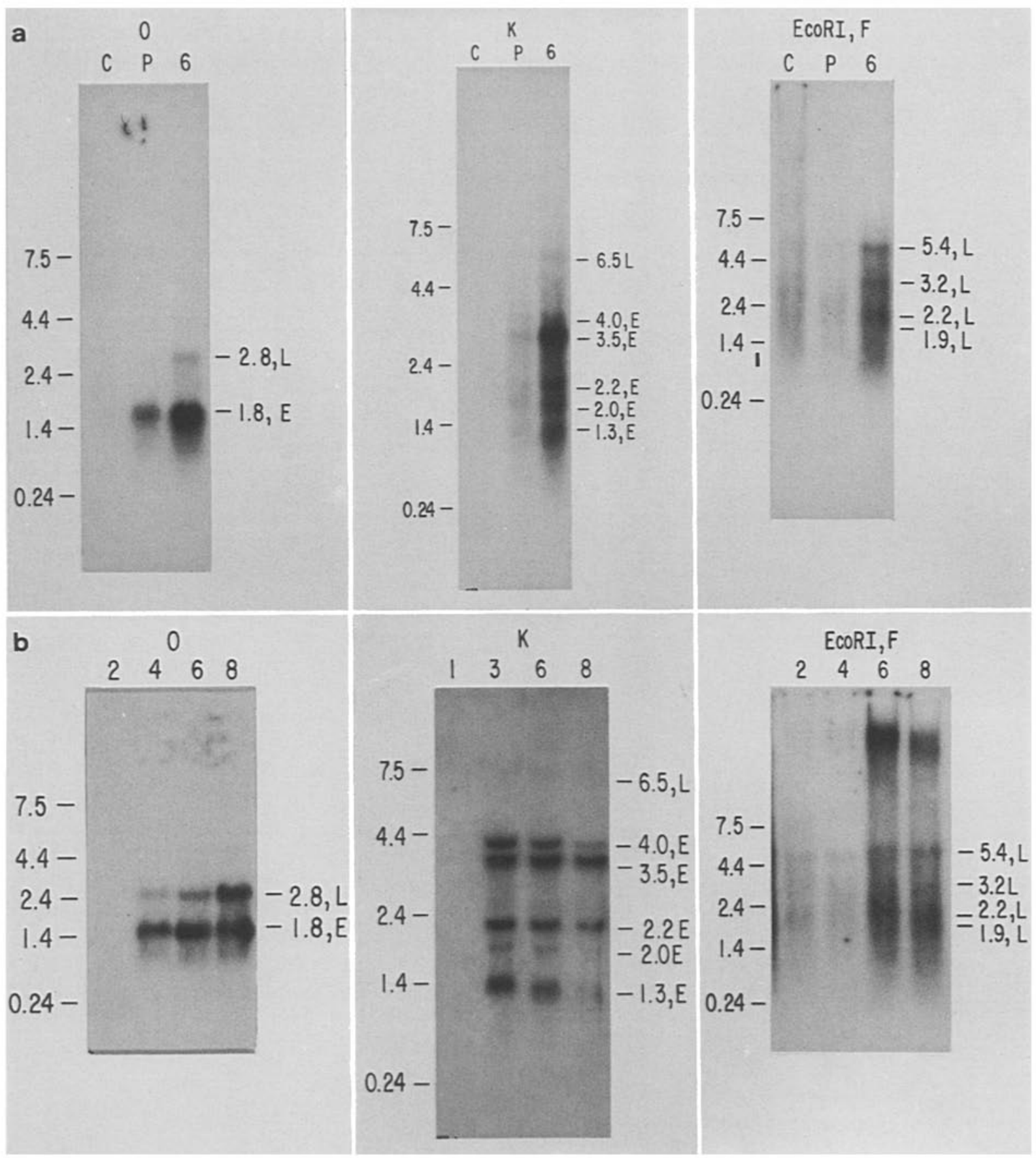

Fig. 6. Blot hybridization analysis of transcripts in BHV-1 Cooper infected bovine cells synthesized from map units 0.842 to 1.000 of the unique short and terminal repeat components of the virus genome. Viral RNA was detected by hybridization with ${ }^{32} \mathrm{P}$-labeled BHV-1 DNA represented by the cloned HindIII fragments $\mathrm{O}$ and $\mathrm{K}$ and the EcoRI $\mathrm{F}$ fragment followed by autoradiography. a RNA purified from BHV-1 infected cells treated with $100 \mu \mathrm{g} / \mathrm{ml}$ cycloheximide $(C), 400 \mu \mathrm{g} / \mathrm{ml}$ phosphonoacetic acid $(P)$ or at $6 \mathrm{~h}$ post infection (p.i.) without drug treatment (6). b RNA purified at various times (h) p.i. as indicated above each lane. Molecular size markers in kilobases are noted to the left of each panel. The size and classification of viral RNA is in the right-hand margin of each panel by molecular size and designated as early $(\mathrm{E})$ or late $(\mathrm{L})$ based upon its detection in the presence or absence of phosphonoacetic acid and its time of appearance 


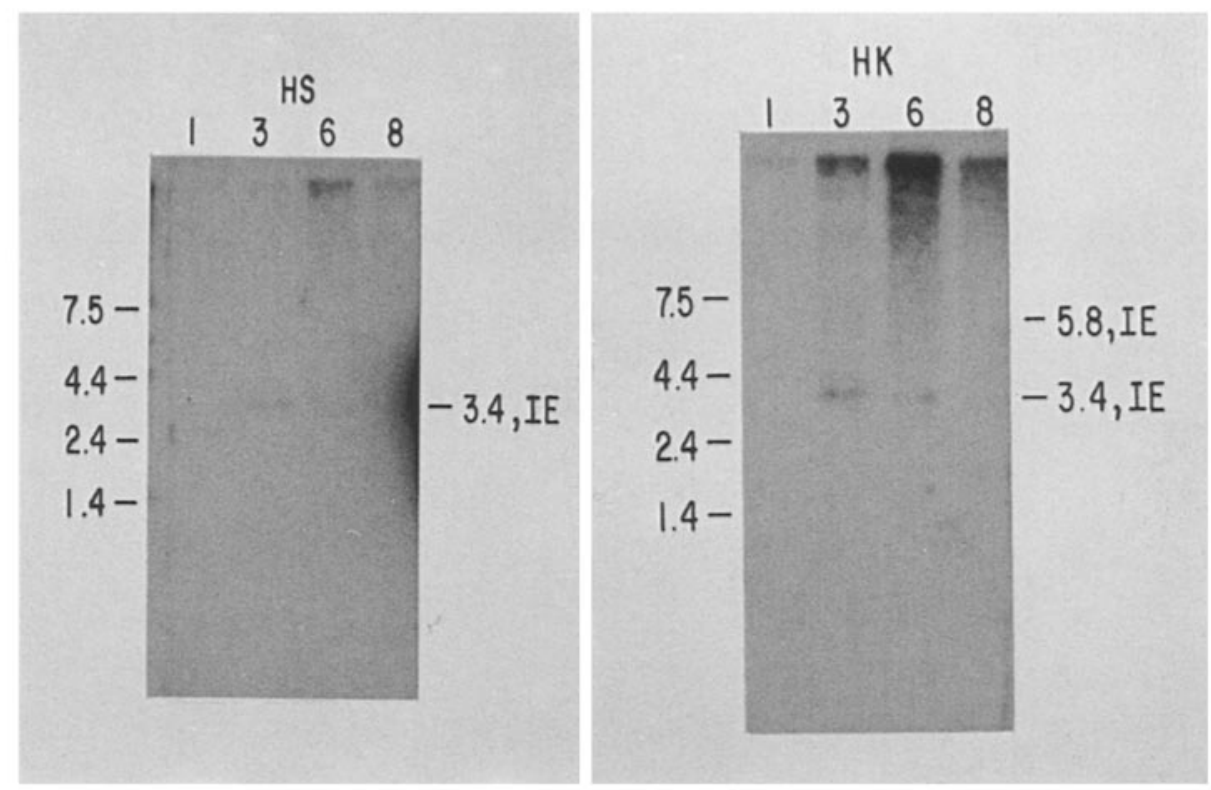

Fig. 7. Blot hybridization analysis of transcripts in BHV-1 Cooper infected bovine cells synthesized from map units 0.734 to 0.778 of the internal inverted repeat sequences of the virus genome. Viral RNA was detected by hybridization with ${ }^{32} \mathrm{P}$-labeled BHV-1 DNA represented by cloned HS $(0.734-0.748 \mathrm{~m} . \mathrm{u}$.) and HK $(0.734-0.778 \mathrm{~m} . \mathrm{u}$.) probes of the HindIII D fragment followed by autoradiography. The panels represent RNA purified at various times (h) p.i. as indicated above each lane. Molecular size markers in kilobases are noted to the left of each panel. Viral RNA is designated as immediate-early (IE) in the right margin of each panel by molecular size

map units 0.734 to 0.842 (Fig. 1). In the presence of $\mathrm{CH}$, transcripts of 2.1, 3.4, and $5.8 \mathrm{~kb}$ were detected (Fig. $5 \mathrm{a}, \mathrm{D}$, lane C). Temporal analysis of BHV-1 infected cell RNA hybridizing to the D fragment at various times p.i. (Fig. $5 \mathrm{~b}$, D) demonstrates that all three transcripts appear in greatest abundance at $3 \mathrm{~h}$ p.i. and then steadily decline later during the BHV-1 infection of cells in culture. No other transcripts were readily identified with any of the other cloned fragments or with the terminal fragment of the BHV-1 genome when hybridized to RNA isolated from BHV-1 infected cells in the presence of $\mathrm{CH}$.

To further characterize from which area of the genome the IE transcripts were synthesized, two subclones from the D fragment designated HS and HK were used as probes at various times p.i. (Fig. 7). The HS probe representing 0.734 to 0.748 m.u. recognized one $3.4 \mathrm{~kb}$ RNA at $3 \mathrm{~h}$ p.i. and at $6 \mathrm{~h}$ p.i., but not at $8 \mathrm{~h}$ p.i. The HK probe ( 0.734 to $0.778 \mathrm{~m}$.u.), which includes the region of the genome encompassed by the HS probe, recognized the $3.4 \mathrm{~kb}$ RNA and an additional $5.8 \mathrm{~kb}$ RNA at the same time points as the HS probe (Fig. 7). Both of these transcripts were detected using the entire HindIII D fragment. It appears that the $3.4 \mathrm{~kb}$ and $5.8 \mathrm{~kb}$ transcripts are synthesized from the left end of the D fragment, while the $2.1 \mathrm{~kb}$ immediate-early RNA may be transcribed from the right terminus of the $\mathrm{D}$ fragment. 
Table 1. Size, classification, and location of transcripts from the genome of the BHV-1 Cooper isolate ${ }^{\mathrm{a}}$

\begin{tabular}{cccccccccccc}
\hline $\mathrm{J}$ & $\mathrm{M}$ & $\mathrm{I}$ & $\mathrm{E}$ & $\mathrm{G}$ & $\mathrm{A}$ & $\mathrm{B}$ & $\mathrm{L}$ & $\mathrm{D}$ & $\mathrm{O}$ & $\mathrm{K}$ & $\mathrm{Eco} \mathrm{F}$ \\
\hline $9.4, \mathrm{~L}$ & $7.3, \mathrm{~L}$ & $6.5, \mathrm{~L}^{\mathrm{b}}$ & $9.0, \mathrm{~L}$ & $10.0, \mathrm{~L}$ & $6.0, \mathrm{E}$ & $7.0, \mathrm{~L}$ & $9.0, \mathrm{~L}$ & $5.8, \mathrm{IE}$ & $2.8, \mathrm{~L}$ & $6.5, \mathrm{~L}$ & $5.4, \mathrm{~L}$ \\
$7.4, \mathrm{E}$ & $6.5, \mathrm{~L}^{\mathrm{b}}$ & $4.5, \mathrm{E}^{\mathrm{c}}$ & $8.5, \mathrm{~L}$ & $5.5, \mathrm{E}$ & $4.5, \mathrm{E}$ & $2.2, \mathrm{~L}$ & $5.0, \mathrm{~L}$ & $3.4, \mathrm{IE}$ & $1.8, \mathrm{E}$ & $4.0, \mathrm{E}$ & $3.2, \mathrm{~L}$ \\
$3.6, \mathrm{E}$ & $4.6, \mathrm{E}^{\mathrm{c}}$ & $3.8, \mathrm{E}$ & $8.0, \mathrm{~L}$ & $4.3, \mathrm{E}$ & $4.0, \mathrm{E}$ & $1.5, \mathrm{E}$ & $3.4, \mathrm{~L}$ & $2.1, \mathrm{IE}$ & & $3.5, \mathrm{E}$ & $2.2, \mathrm{~L}$ \\
$2.4, \mathrm{E}$ & $2.5, \mathrm{E}$ & $2.6, \mathrm{E}$ & $4.1, \mathrm{~L}$ & $1.6, \mathrm{E}$ & $3.5, \mathrm{E}$ & & $2.8, \mathrm{E}$ & $1.6, \mathrm{~L}$ & & $2.2, \mathrm{E}$ & $1.9, \mathrm{~L}$ \\
$2.2, \mathrm{E}$ & $2.0, \mathrm{~L}$ & $2.1, \mathrm{~L}$ & $1.8, \mathrm{E}$ & $0.8, \mathrm{~L}$ & $1.6, \mathrm{~L}$ & & $1.8, \mathrm{~L}$ & & & $2.0, \mathrm{E}$ & \\
$1.8, \mathrm{E}$ & & $1.8, \mathrm{~L}$ & & & & & $1.0, \mathrm{~L}$ & & & $1.3, \mathrm{E}$ & \\
& & $1.2, \mathrm{E}$ & & & & & & & & & \\
& & $0.6, \mathrm{E}$ & & & & & & & & & \\
\hline $5 \mathrm{E}$ & $2 \mathrm{E}$ & $5 \mathrm{E}$ & $1 \mathrm{E}$ & $3 \mathrm{E}$ & $4 \mathrm{E}$ & $1 \mathrm{E}$ & $1 \mathrm{E}$ & $3 \mathrm{IE}$ & $1 \mathrm{E}$ & $5 \mathrm{E}$ & $4 \mathrm{~L}$ \\
$1 \mathrm{~L}$ & $3 \mathrm{~L}$ & $3 \mathrm{~L}$ & $4 \mathrm{~L}$ & $2 \mathrm{~L}$ & $1 \mathrm{~L}$ & $2 \mathrm{~L}$ & $5 \mathrm{~L}$ & $1 \mathrm{~L}$ & $1 \mathrm{~L}$ & $1 \mathrm{~L}$ & \\
\hline
\end{tabular}

${ }^{a}$ Transcript sizes in kilobases were determined by extrapolation between the relative mobilities of the RNA size markers. Classification and location of transcripts were assigned by their detection during cycloheximide treatment (IE immediate-early), phosphonoacetic acid treatment ( $E$ early), or no drug treatment ( $\mathrm{L}$ late) and hybridization with the specific HindIII fragment listed or the EcoRI F fragment

${ }^{b, c}$ Specific RNAs of similar size and temporal classification which were detected by two different fragments, possibly due to transcription across a restriction enzyme site

\section{Identification of early transcripts}

For detection of early transcripts, RNA was isolated from BHV-1 infected cells with PAA at $6 \mathrm{~h}$ p.i. Twenty-eight early transcripts were detected across the BHV-1 genome using all the cloned HindIII fragments except the HindIII D fragment (Table 1). Twelve early transcripts were identified using the HindIII fragments J, M, and I (Fig. 3 and Table 1) encompassing 0.018 to 0.195 m.u. of the BHV-1 genome (Fig. 1).

Specifically, five early transcripts of $1.8,2.2,2.4,3.6$, and $7.4 \mathrm{~kb}$ were detected using the $\mathrm{J}$ fragment, two 2.6 and $4.6 \mathrm{~kb}$ early transcripts were identified using the HindIII M fragment (Fig. 3 and Table 1) and five early transcripts detected using the HindIII I fragment were $0.6,1.2,2.6,3.8$, and $4.5 \mathrm{~kb}$ in size. The $4.6 \mathrm{~kb}$ RNA listed as arising from the $\mathrm{M}$ fragment and the $4.5 \mathrm{~kb}$ RNA detected using the I fragment quite possibly were synthesized across the restriction enzyme site (Table 1). This conclusion was substantiated by comparison of the time course of their appearance in BHV-1 infected cell RNA (Fig. 3b, M and I).

From the HindIII E, G, and A fragments (Fig. 4 and Table 1) comprising 0.195 to $0.537 \mathrm{~m}$.u. of the unique long component of the BHV-1 genome (Fig. 1), 
eight early transcripts were identified. A single $1.8 \mathrm{~kb}$ early RNA was detected using the $\mathrm{E}$ fragment, while three early transcripts of $1.6,4.3$, and $5.5 \mathrm{~kb}$ were identified with the $G$ fragment. Four early transcripts of $3.5,4.0,4.5$, and $6.0 \mathrm{~kb}$ were detected by the HindIII A fragment of the BHV-1 genome (Fig. 4 and Table 1). Analysis of the temporal appearance of these transcripts (Fig. 4b, E, $\mathrm{G}$, and $\mathrm{A}$ ), along with the appearance of each individual RNA in the presence of PAA (Fig. 4a, E, G, and A), indicates that these are individual transcripts arising from within the area of the genome represented by each fragment with none appearing to cross HindIII restriction enzyme sites.

The area of the genome from 0.537 to $0.842 \mathrm{~m}$.u., covering portions of the unique long, the internal inverted repeat, and into the unique short region of the genome, is represented by the HindIII fragments B, L, and D (Fig. 1). From this region of the genome only two early transcripts were identified. Using the B fragment, a $1.5 \mathrm{~kb}$ early RNA was detected, and a $2.8 \mathrm{~kb}$ early RNA was synthesized from the $\mathrm{L}$ fragment (Fig. 5 and Table 1). The appearance of these transcripts in the presence of PAA (Fig. 5a) and at various times p.i. (Fig. 5b) is consistent with the definition of early transcripts.

Early transcripts arising from the area of the BHV-1 genome from 0.842 to 1.000 m.u. of the $\mathrm{U}_{\mathrm{S}}$ component of the BHV-1 genome were identified using the HindIII $\mathrm{O}$ and $\mathrm{K}$ fragments along with the EcoRI fragment $\mathrm{F}$ (Fig. 1). A $1.8 \mathrm{~kb}$ early RNA was detected using the $\mathrm{O}$ fragment, while five early transcripts of $1.3,2.0,2.2,3.5$, and $4.0 \mathrm{~kb}$ were detected using the HindIII $\mathrm{K}$ fragment (Fig. 6 and Table 1). No early transcripts were found using the terminal EcoRI F fragment as a probe (Fig. 6 and Table 1).

\section{Identification of late transcripts}

A total of 28 late transcripts were identified throughout the entire BHV-1 genome. These transcripts were identified by their appearance late $(6-8 \mathrm{~h} \mathrm{p.i.)}$ during the BHV-1 infection and in the absence of metabolic inhibitors. Seven late transcripts were identified using the cloned HindIII fragments J, M, and I (Fig. 3 and Table 1) representing 0.018 to $0.195 \mathrm{~m} . \mathrm{u}$. of the BHV-1 genome (Fig. 1). A $9.4 \mathrm{~kb}$ late RNA was detected using the $\mathrm{J}$ fragment, while 6.5 and $2.0 \mathrm{~kb}$ transcripts were identified using the $M$ fragment (Fig. 3 and Table 1). The largest number of transcripts was detected using the I fragment (Fig. 3 and Table 1) and of these, three were classified as late. The 1.8 and $2.1 \mathrm{~kb}$ RNAs of the I fragment appear to be transcribed exclusively from within the I fragment. However, the $6.5 \mathrm{~kb}$ late RNA may be shared by the $\mathrm{M}$ fragment (Fig. 3 and Table 1).

Transcription from the unique long section of the BHV-1 genome encompassing map units 0.195 to 0.537 was analyzed by RNA blot hybridization using the HindIII restriction fragments E, G, and A (Fig. 4 and Table 1). Transcripts identified using fragment E were 4.1,8.0, 8.5, and $9.0 \mathrm{~kb}$ in size (Fig. 4). From the G fragment two late RNAs of 0.8 and $10.0 \mathrm{~kb}$ were detected without the use of PAA (Fig. $4 \mathrm{a}, \mathrm{G}$ ). A single $1.6 \mathrm{~kb}$ late RNA was identified within 
the A fragment which contained predominantly early transcripts (Fig. 4 and Table 1).

Using the HindIII B, L, and D fragments encompassing the "far right" of the unique long, the inverted repeat and into the unique short region of the BHV-1 genome ( 0.537 to 0.842 m.u.) seven late transcripts were identified (Fig. 5 and Table 1). Two late RNAs of 2.2 and $7.0 \mathrm{~kb}$ were detected with the HindIII $\mathrm{B}$ fragment. Using the L fragment for RNA blot hybridization, five late transcripts could be identified with sizes of $1.0,1.8,3.4,5.0$, and $9.0 \mathrm{~kb}$. However, a $1.6 \mathrm{~kb}$ late RNA was identified using the D fragment (Fig. 5 and Table 1). Since neither the HS or HK probes from the left terminus of the D fragment detect this RNA (Fig. 7), it may be inferred that this $1.6 \mathrm{~kb}$ late RNA is transcribed from the right side of the $\mathrm{D}$ fragment.

Transcription from the unique short section of the BHV-1 genome from map units 0.842 to 1.0 was investigated using the HindIII fragments $\mathrm{O}$ and $\mathrm{K}$ and the $E c o$ RI $F$ fragment (Fig. 1). One $2.8 \mathrm{~kb}$ late RNA was detected with the $\mathrm{O}$ fragment. Using the $\mathrm{K}$ fragment, which primarily codes for early transcripts, a single $6.5 \mathrm{~kb}$ late RNA was identified (Fig. 6 and Table 1). The right terminus of the BHV-1 Cooper genome is represented by the EcoRI F fragment (Fig. 1) and four late transcripts were identified as being synthesized from this section of the genome (Fig. 6 and Table 1). These transcripts were 1.9, 2.2, 3.2, and $5.4 \mathrm{~kb}$ in size.

\section{Discussion}

Fifty-nine transcripts ranging in size from 0.6 to $10 \mathrm{~kb}$ were detected during a productive infection of bovine cells in culture by the BHV-1 Cooper isolate. These transcripts were categorized into three temporal classes based upon two sets of criteria. Analysis was organized by the ability to detect individual transcripts from infected cells treated specifically with $\mathrm{CH}$, PAA, or without drug treatment. Appearance of specific transcripts was also monitored temporally during a BHV-1 infection of cells in culture. Such a thorough examination of BHV-1 transcription has enabled us to unequivocally characterize individual transcripts. The number of transcripts and classification scheme are similar to results obtained using cloned double-stranded viral genomic DNA probes for varicella zoster virus $[40,43]$, herpes simplex virus type 1 (HSV-1; [60]) and equine herpesvirus 1 [16]. The 59 transcripts are five greater than the 54 transcripts reported previously for BHV-1 [58]. This may be due to the fact that, during the studies reported here, the terminal EcoRI F fragment was also used to identify four additional transcripts.

Using the metabolic inhibitor $\mathrm{CH}$, three immediate-early transcripts were identified as being synthesized from the inverted repeat region of the BHV-1 genome at ( 0.734 to $0.842 \mathrm{~m}$.u.) encompassing the HindIII D fragment. In this study the sizes were determined to be $2.1,3.4$, and $5.8 \mathrm{~kb}$, whereas three immediate-early transcripts were previously reported to be $1.6,2.9$, and $4.2 \mathrm{~kb}$ in size [58]. The HS probe covering the left terminus of the HindIII D fragment 
(0.734 to 0.748 m.u.) corresponds to the area of the BHV-1 genome where latency-associated transcription occurs [44]. Using this fragment, a $3.4 \mathrm{~kb}$ RNA was detected. A larger fragment, the HK probe $(0.734$ to 0.778 m.u.), detected the $3.4 \mathrm{~kb}$ RNA, and an additional $5.8 \mathrm{~kb}$ immediate-early RNA. Results using the HS and HK probes indicate that these two transcripts arise from the left side of the D fragment, while the $2.1 \mathrm{~kb}$ immediate-early RNA and the $1.6 \mathrm{~kb}$ late RNA arise from the right side of the HindIII D fragment. A fourth immediate-early transcript of $1.8 \mathrm{~kb}$ was also reported in this region of the genome [58]. During the investigations reported here a $1.6 \mathrm{~kb}$ transcript was identified, but found not to be produced in the presence of $\mathrm{CH}$ and only at late times during infection.

Using the herpesvirus DNA polymerase inhibitor PAA [26], 28 transcripts were categorized in the early class. An earlier study demonstrated a greater resistance of BHV-1 to PAA than other herpesviruses [1]. Consequently, optimum concentrations of PAA were determined and a concentration of $400 \mu \mathrm{g} /$ ml PAA was used to identify the early transcripts. As with other herpesviruses, early transcription was not limited to specific areas of the genome $[16,40,60]$. A number of early genes have now been mapped and their location within the BHV-1 genome corresponds to areas where clusters of early transcripts were identified during this study. The gI (gB homologue of HSV) gene of BHV-1 has been localized from 0.405 to 0.432 m.u. $[24,38,57]$ and the thymidine kinase gene has been placed at map units 0.470 to 0.480 [39] of the BHV-1 Cooper HindIII A fragment ( 0.381 to 0.537$)$. Five early transcripts ranging in size from $3.5 \mathrm{~kb}$ to $6.0 \mathrm{~kb}$ were detected using the A fragment for RNA blot hybridization. Specifically, a transcript of $4.5 \mathrm{~kb}$ was identified that is equivalent to the size estimate of the transcript from the cloned BHV-1 TK gene (L. J. Bello, University of Pennsylvania, Philadelphia, PA, pers. comm.). This $4.5 \mathrm{~kb}$ early transcript was unreported from this area of the genome in earlier work [58]. Two other early genes that have been identified include the BHV-1 DNA polymerase gene at map units 0.334 to 0.352 [41] and a putative DNA binding protein gene localized from map units 0.352 to 0.381 [2] within the HindIII G fragment of BHV-1 Cooper ( 0.294 to 0.381 ). Three early transcripts have been identified in this region during these studies. Size estimates of the DNA polymerase and DNA binding protein genes $[2,4]$ of BHV-1 correspond to the $1.6 \mathrm{~kb}$ and $4.3 \mathrm{~kb}$ early RNAs described here. Both the HindIII I fragment ( 0.110 to $0.195 \mathrm{~m} . \mathrm{u}$.) of the unique long and the HindIII K fragment ( 0.845 to 0.907 m.u.) of the unique short areas of the BHV-1 genome contained clusters of early transcripts. Unlike a previous report [58], we show that the HindIII I fragment coded for the greatest number of transcripts from the BHV-1 genome and the sizes of transcripts reported herein are larger. Glycoprotein gIV (gD homologue of HSV) mapped to the HindIII K fragment between 0.892 and 0.902 m.u. [53]. In addition to gIV, preliminary investigations have demonstrated the $\mathrm{K}$ fragment also codes for a cluster of glycoprotein genes including $\mathrm{gE}$, gI, and $\mathrm{gX} / \mathrm{G}$ (T. Zamb, Veterinary Infectious Disease Organization, Uni- 
versity of Saskatchewan, Saskatoon, Saskatchewan, pers. comm.) in a situation similar to HSV-1 [60].

In the absence of metabolic inhibitors and based upon detection of individual RNAs following the initiation of BHV-1 DNA synthesis at 4 to $5 \mathrm{~h}$ p.i., 28 late transcripts were identified. As in early gene expression, late transcripts were located throughout the genome. However, the HindIII E fragment $(0.195$ to 0.294 m.u.) and the HindIII L fragment ( 0.678 to 0.734 m.u.) of the unique long section of the BHV-1 genome recognized predominantly late RNA. The EcoRI F fragment (0.936 to 1.0 m.u.) representing the right terminus of the $\mathrm{BHV}-1$ genome recognized only transcripts of the late class. One late $1.6 \mathrm{~kb}$ RNA was detected using the HindIII D fragment, which otherwise recognized primarily immediate-early RNA. The glycoprotein gIII (gC) gene of BHV-1 has been cloned, sequenced, and the gene has been localized at map units 0.122 to 0.135 m.u. of the HindIII I fragment $[12,13]$. The gIII gene is approximately $1.6 \mathrm{~kb}$ in size [12] and most likely corresponds to the $1.8 \mathrm{~kb}$ late RNA recognized by the I fragment during this investigation. Preliminary data using the cloned BHV-1 gIII gene have confirmed this (unpubl.). In previous transcriptional studies only 12 transcripts were identified as possibly belonging to the late class [58]. Using metabolic inhibitors along with temporal analysis of BHV-1 RNA synthesis, 28 late transcripts were specifically identified during these investigations.

\section{Acknowledgements}

Appreciation is extended to Dr. John E. Mayfield of Iowa State University and Dr. Daniel Rock of the Plum Island Animal Disease Center, USDA, for sharing their genomic DNA clones of the BHV-1 Cooper isolate, to Sandy Johnson for secretarial assistance, and to Gene Hedberg, Tom Glasson, and Wayne Romp for graphics and photography. We also thank Dr. Julia Ridpath, Dr. Geoffrey Letchworth, Dr. Irene Wesley, and Robert B. Klieforth for critical review. These investigations were supported by USDA CRIS 363034000-016-00D.

\section{References}

1. Babiuk LA, Acres SD, Misra V, Stockdale PHG, DeClerq E (1983) Susceptibility of bovine herpesvirus 1 to antiviral drugs: In vitro versus in vivo efficacy of (E)-5-(2bromovinyl)-2'-deoxyuridine. Antimicrob Agents Chemother 23: 715-720

2. Bandyopadhyay SK, Mittal SK, Field HJ (1990) Identification of the gene homologous to HSV major DNA binding protein in the BHV-1 genome. Vet Microbiol 22: 203212

3. Bello LJ, Whitbeck JC, Lawrence WC (1987) Map location of the thymidine kinase gene of bovine herpesvirus 1. J Virol 61: 4023-4025

4. Bolton DC, Zee YC, Ardans AA (1983) Identification of envelope and nucleocapsid proteins of infectious bovine rhinotracheitis virus by SDS-PAGE. Vet Microbiol 8: $57-68$

5. Caughman GB, Staczek J, O'Callaghan DJ (1985) Equine herpesvirus type 1 infected cell polypeptides: evidence for immediate early/early/late regulation of viral gene expression. Virology 145: 49-61 
6. Chirgwin JM, Przybyla AE, MacDonald RJ, Rutter WJ (1979) Isolation of biologically active ribonucleic acid from sources enriched in ribonuclease. Biochemistry 18: 5294 5299

7. Church GM, Gilbert W (1984) Genomic sequencing. Proc Natl Acad Sci USA 81: 1991-1995

8. Engels M, Gelderblom H, Darai G, Ludwig H (1983) Goat herpesvirus: biological and physicochemical properties. J Gen Virol 64: 2237-2247

9. Engels M, Giuliani C, Wild P, Beck TM, Leopfe E, Wyler R (1986) The genome of BHV 1 strains exhibiting a neuropathogenic potential compared to known BHV-1 strains by restriction site mapping and cross hybridization. Virus Res 6: 57-73

10. Feinberg AP, Vogelstein B (1983) A technique for radiolabeling DNA restriction endonuclease fragments to high specific activity. Anal Biochem 132: 6-13

11. Feinberg AP, Vogelstein B (1984) A technique for radiolabeling DNA restriction endonuclease fragments to high specific activity. Addendum. Anal Biochem 137: 266267

12. Fitzpatrick DR, Babiuk LA, Zamb TJ (1989) Nucleotide sequence of bovine herpesvirus type 1 glycoprotein gIII, a structural model for gIII as a new member of the immunoglobulin superfamily, and implications for the homologous glycoproteins of other herpesviruses. Virology 173: 46-57

13. Fitzpatrick DR, Zamb T, Parker MD, van Drunen Littel-van den Hurk S, Babiuk LA, Lawman MJP (1988) Expression of bovine herpesvirus 1 glycoprotein gI and gIII in transfected murine cells. J Virol 62: 4239-4248

14. Glisin V, Crkvenjakov R, Byers C (1974) Ribonucleic acid isolated by cesium chloride centrifugation. Biochemistry 13: 2633-2637

15. Graham BJ, Ludwig H, Bronson DL, Benyesh-Melnick M, Biswal N (1972) Physicochemical properties of the DNA of herpesviruses. Biochem Biophys Acta 259: 1323

16. Gray WL, Bauman RP, Robertson AT, O'Callaghan DJ, Staczek J (1987) Characterization and mapping of equine herpesvirus type 1 immediate early, early and late transcripts. Virus Res 8: 233-244

17. Hammerschmidt W, Ludwig H, Buhk H-J (1988) Specificity of cleavage in replicativeform DNA of bovine herpesvirus 1. J Virol 62: 1355-1363

18. Hammerschmidt W, Ludwig H, Buhk H-J (1986) Short repeats cause heterogeneity at genomic terminus of bovine herpesvirus 1. J Virol 58: 43-49

19. House JA (1972) Bovine herpesvirus: IBR-IPV strain differences. Cornell Vet 62: 431453

20. Jones C, Delhon G, Bratanich A, Kutich G, Rock D (1990) Analysis of the transcriptional promoter which regulates the latency-related transcript of bovine herpesvirus 1 . J Virol 64: 1164-1170

21. Kendrick JW, Gillespie JH, McEnter K (1958) Infectious pustular vulvovaginitis of cattle. Cornell Vet 48: 458-495

22. Kit S, Qavi H (1983) Thymidine kinase (Tk) induction after infection of Tk-deficient rabbit cell mutants with bovine herpesvirus type 1 (BHV-1): isolation of TK - BHV1 mutants. Virology 130: 381-389

23. Kokles R (1967) In: Roher H (ed) Handbuch der Virusinfektionen bei Tieren, vol 2. VEB G Fischer, Jena, pp 901-960

24. Lawrence WC, D'Urso RC, Kundel CA, Whitbeck JC, Bello L (1986) Map location of the gene for a 130,000-dalton glycoprotein of bovine herpesvirus 1. J Virol 60: 405414

25. Lehrach H, Diamond D, Wozney JM, Boedtker H (1977) RNA molecular weight determinations by gel electrophoresis under denaturing conditions, a critical examination. Biochemistry 16: 4743-4751 
26. Leinback SS, Reno JM, Lee LF, Isbell AF, Boezi JA (1976) Mechanism of phosphonoacetate inhibition of herpesvirus-induced DNA polymerase. Biochemistry 15: $426-430$

27. Ludwig H (1983) Bovine herpesviruses. In: Roizman B (ed) The herpesviruses. Plenum, New York, pp 135-214

28. Madin SH, York CJ, McKercher DG (1956) Isolation of infectious bovine rhinotracheitis virus. Science 124: 721-722

29. Mahmoudi M, Lin VK (1989) Comparison of two different hybridization systems in Northern transfer analysis. Biotechniques 7: 331-334

30. Maniatis T, Fritsch EF, Sambrook J (1982) Molecular cloning: a laboratory manual. Cold Spring Harbor Laboratory, Cold Spring Harbor, NY

31. Marshall RL, Rodriguez LL, Letchworth GJ (1986) Characterization of envelope proteins of infectious bovine rhinotracheitis virus (bovine herpesvirus 1) by biochemical and immunological methods. J Virol 57: 745-753

32. Mayfield JE, Good PJ, Van Oort HJ, Campbell AR, Reed DE (1983) Cloning and cleavage site mapping of DNA from bovine herpesvirus 1 (Cooper strain). J Virol 47: 259-264

33. McMaster GK, Carmichael GC (1977) Analysis of single- and double-stranded nucleic acids on polyacrylamide and agarose gels by using glyoxal and acridine orange. Proc Natl Acad Sci USA 74: 4835-4838

34. Metzler AE, Schudel AA, Engels M (1986) BHV 1 molecular and antigenic characteristics of variant viruses isolated from calves with neurologic disease. Arch Virol 87: 205-217

35. Miller NJ (1955) Infectious necrotic rhinotracheitis of cattle. J Am Vet Med Assoc 126: $463-467$

36. Misra V, Babiuk LA, Le Q Darcel C (1983) Analysis of bovine herpes virus type 1 isolates by restriction endonuclease fingerprinting. Arch Virol 76: 341-354

37. Misra V, Blumenthal RM, Babiuk LA (1983) Proteins specified by bovine herpesvirus 1 (infectious bovine rhinotracheitis). J Virol 40: 367-378

38. Misra V, Nelson R, Smith M (1988) Sequence of a bovine herpesvirus type-1 glycoprotein gene that is homologous to the Herpes simplex gene for the glycoprotein $\mathrm{gB}$. Virology 166: 542-549

39. Mittal SK, Field HJ (1989) Analysis of the bovine herpesvirus type 1 thymidine kinase (Tk) gene from wild-type and Tk ${ }^{-}$deficient mutants. J Gen Virol 70: 901-918

40. Ostrove JM, Reinhold W, Fan C-M, Zorn S, Hay J, Strauss SE (1985) Transcription mapping of the varicella zoster virus genome. J Virol 56: 600-606

41. Owen LJ, Field HJ (1988) Genomic localization and sequence analysis of the putative bovine herpesvirus-1 DNA polymerase gene. Arch Virol 98: 27-38

42. Pastoret PP, Thiry E, Brochier B, Derboven G (1982) Bovid herpesvirus 1 infection of cattle: pathogenesis, latency, consequences of latency. Ann Rech Vet 13: 221-235

43. Reinhold WC, Strauss SE, Ostrove JM (1988) Directionality and further mapping of varicella zoster virus transcripts. Virus Res 9: $249-261$

44. Rock DL, Beam SL, Mayfield JE (1987) Mapping BHV 1 latency-related RNA in trigerminal ganglia of latently infected rabbits. J Virol 61: 3827-3831

45. Sabina LR, Parker RC (1963) Studies of infectious bovine rhinotracheitis virus. I. Plaque assay and some characteristics in bovine kidney cells. Can J Microbiol 9: 567576

46. Seal BS, Martinez JD, Hall MR, St Jeor SC (1988) Occurrence of bovine herpesvirus1 DNA in nucleosomes of bovine herpesvirus-1 infected cells. Identification of a virion associated protein in chromatin of infected cells. Arch Virol 99: 221-236

47. Seal BS, St Jeor SC (1988) Purification and characterization of bovine herpesvirus-1 isolates and virus DNA utilizing bovine embryonic lung cells. J Tissue Cult Methods 11: $42-48$ 
48. Seal BS, St Jeor SC, Taylor REL (1985) Restriction endonuclease analysis of bovine herpesvirus-1 DNA and nucleic acid homology between isolates. J Gen Virol 66: 2787

49. Stevens JG, Groman NB (1963) Properties of infectious bovine rhinotracheitis virus in a quantitated virus-cell culture system. Am J Vet Res 24: 1158-1163

50. Stevens JG, Groman NB (1964) Infectious bovine rhinotracheitis virus replication, cytopathology, and plaque formation in the presence and absence of nucleid acid analogues. J Bacteriol 87: 446-453

51. Struhl K (1985) A rapid method for creating recombinant DNA molecules. Biotechniques 3: 452

52. Studdert MJ (1990) Bovine encephalitis herpesvirus. Vet Rec 126: 21-22

53. Tikoo SK, Fitzpatrick DR, Babiuk LA, Zamb TJ (1990) Molecular cloning, sequencing, and expression of functional bovine herpesvirus 1 glycoprotein gIV in transfected bovine cells. J Virol 64: 5132-5142

54. Weinmaster GA, Misra V, McGuire R, Babiuk LA, DeClerq E (1982) Bovine herpesvirus type-1 (infectious bovine rhinotracheitis virus)-induced thymidine kinase. Virology 118: 191-201

55. Whetstone CA, Miller JM, Bortner DM, Van Der Maaten MJ (1989) Changes in the restriction endonuclease patterns of four modified-live infectious bovine rhinotracheitis virus (IBRV) vaccines after one passage in the host animal. Vaccine 7: 527-532

56. Whetstone CA, Wheeler JG, Reed DE (1985) Investigation of possible vaccine-induced epizootics of infectious bovine rhinotracheitis, using restriction endonuclease analysis of viral DNA. Am J Vet Res 47: 1789-1795

57. Whitbeck JC, Bello LJ, Lawrence WC (1988) Comparison of the BHV 1 gI gene and the HSV $1 \mathrm{gB}$ gene. J Virol 62: 3319--3327

58. Wirth UV, Gunkel K, Engels M, Schwyzer M (1989) Spatial and temporal distribution of bovine herpesvirus 1 transcripts. J Virol 63: 4882-4889

59. Wyler R, Engels M, Schwyzer M (1989) Infectious bovine rhinotracheitis/vulvovaginitis (BHV 1). In: Wittman G (ed) Herpesvirus diseases of cattle, horses, and pigs. Kluwer, Boston, pp 1-72

60. Zhang Y-F, Wagner EK (1987) The kinetics of expression of individual herpes simplex type 1 transcripts. Virus Genes 1: 49-60

Authors' address: Dr. B. S. Seal, USDA, ARS, National Animal Disease Center, P.O. Box 70, 2300 Dayton Road, Ames, IA 50010, U.S.A.

Received January 18, 1991 